\author{
RAFAE P. PipreK ${ }^{1}$, JACEK Z. KUBiaK ${ }^{2,3}$ \\ ${ }^{1}$ Zakład Anatomii Porównawczej \\ Instytut Zoologii i Badań Biomedycznych \\ Uniwersytet Jagielloński \\ Gronostajowa 9, 30-387 Kraków \\ ${ }^{2}$ UnivRennes, CNRS, UMR 6290 \\ Institute of Genetics and Development of Rennes \\ Cell Cycle Group, Faculty of Medicine \\ F-35000 Rennes, Francja \\ ${ }^{3}$ Zakład Medycyny Regeneracyjnej i Biologii Komórki \\ Wojskowy Instytut Higieny i Epidemiologii (WIHE) \\ Kozielska 4, 01-163 Warszawa \\ E-mail: rafal.piprek@uj.edu.pl
}

\title{
DETERMINACJA PŁCI I ROZWÓJ GONAD KURY DOMOWEJ
}

\section{WSTEP}

W trakcie rozwoju embrionalnego kury gonady, czyli jądra i jajniki, powstają ze wspólnych, morfologicznie identycznych i niezróżnicowanych płciowo zawiązków. Rozwój zawiązków gonad w kierunki jednej $z$ płci zależy od determinacji płci kształtujacego się osobnika. Zarówno proces determinacji płci, jak i płciowego różnicowania się gonad został najlepiej poznany u myszy laboratoryjnej (PIPREK i współaut. 2016). Determinacja płci była również badana u kury domowej (SMITH i współaut. 1997, 2003, 2008, 2009). Głównym powodem licznych badań nad rozwojem kur jest znaczenie tego gatunku w ekonomii człowieka. Dla rolnictwa cenne sa przede wszystkim samice kury, gdyż to one dostarczaja jaj. Natomiast większość młodych samców jest eliminowana tuż po wykluciu, kiedy możliwe jest rozpoznanie płci. Badania nad determinacja płci maja na celu opracowanie metod seksowania osobników na jak najwcześniejszym etapie rozwoju in ovo (w jaju) (KRAUTWALD-JUNGHANNS i współaut. 2018). Ponadto, możliwość manipulowania płcia kur, a nawet uzyskanie jednopłciowych linii okazałoby się niezwykle cenne dla przemysłu drobiarskiego i umożliwiłoby uniknięcie ko- nieczności eliminacji dużej części osobników męskich (PREISINGER 2003).

Ptaki stanowia obszerna gromade kręgowców liczaca około 10 tysięcy gatunków. Mimo tak wysokiej liczebności gatunków, pod względem determinacji płci jest to jednak grupa jednolita, gdyż u wszystkich samców występuja chromosomy płci ZZ, a u samic $Z W$. Pod względem ekspresji genów i zmian strukturalnych zachodzacych w rozwoju gonad ptaków najlepiej zbadana została kura domowa (Gallus gallus domesticus) (Sмith i współaut. 1997, 2003, 2008, 2009). Gatunek ten zaliczany jest do rzędu ptaków grzebiących, kuraków (Galliformes) i rodziny kurowatych (Phasianidae). Kura domowa hodowana jest obecnie na całym świecie i stanowi udomowiona formę kura bankiwa (Gallus gallus), gatunku zamieszkujacego północno-wschodnie tereny Indii i Azję południowo-wschodnią. Udomowienie kury miało miejsce prawdopodobnie w III tysiącleciu p.n.e. w Indiach, chociaż niektóre badania wskazały, że być może stało się to już w VI tysiącleciu p.n.e w Chinach (WEST i ZHOU 1988). Kury hodowano powszechnie już w Starożytnym Egipcie i w Europie 500 lat p.n.e. Gatunek ten jest znaczacym źródłem pożywienia dla ludzi, a od ponad 100 lat stanowi organizm modelowy dla badań naukowych, m.in. $z$ dziedziny embrio-

Słowa kluczowe: aromataza, chromosomy płci, determinacja płci, estradiol, gonady, hormony płci, kura domowa, testosteron 
logii ze względu na łatwa dostępność materiału badawczego.

\section{DETERMINACJA PŁCI}

U ptaków płeć determinowana jest genetycznie podczas zapłodnienia. Wówczas to plemnik niosacy chromosom płci $Z$ łączy się Z oocytem zawierajacym chromosom $Z$ lub W (Ryc. 1). U ptaków płeć żeńska jest płcia heterogametyczna $\mathrm{ZW}$, u której gamety zawieraja po jednym $z$ dwóch różnych chromosomów płci, a płeć męska homogametyczną ZZ, u której gamety zawierają zawsze ten sam chromosom płci

Ptasie chromosomy płci ( $\mathrm{Z}$ i W) nie sa jednak homologiczne $z$ chromosomami plciowymi ssaków ( $\begin{aligned} & \mathrm{X} \\ & \text { i }\end{aligned}$ innej pary chromosomów autosomalnych wspólnych przodków obu grup, którymi były wymarłe gady (GRAVES 2016). U większości gatunków ptaków chromosomy Z i W sa heteromorficzne, a więc znacznie różnia się morfologicznie, dzięki czemu można je rozróżnić pod mikroskopem stosując odpowiednie barwienia. Wyjatkiem sa ptaki paleognatyczne (grupa ptaków posiadajacych prymitywna budowę podniebienia, do której należą strusie, nandu, kusacze, kiwi i kazuary), u których chromosomy płci $\mathrm{Z}$ i W sa izomorficzne, czyli nie różniące się w sposób istotny długością (XU i współaut. 2018).

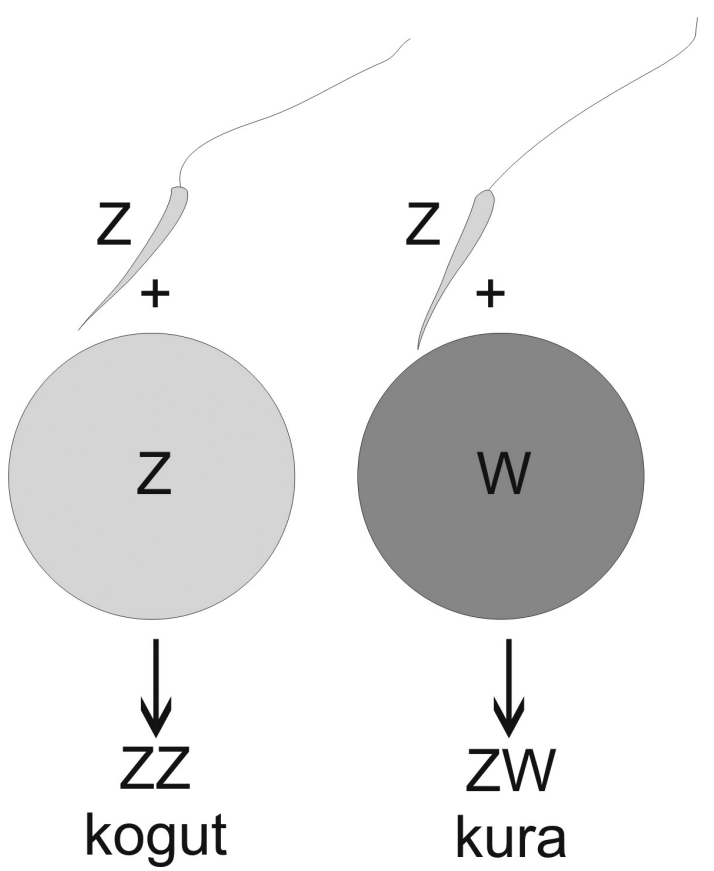

Ryc. 1. Determinacja płci podczas zapłodnienia ptaków.

W wyniku połączenia się komórki jajowej $Z$ z plemnikiem $Z$ rozwija się osobnik $Z Z$, genetyczny samiec. W wyniku połączenia się komórki jajowej $\mathrm{W}$ z plemnikiem $Z$ rozwija się osobnik $Z W$ - genetyczna samica.
Tradycyjny model determinacji płci zakłada, że chromosomy płci determinuja różnicowanie się zawiązków gonad w jądra lub jajniki, które następnie, przez wydzielane hormony płciowe, kieruja rozwojem cech płciowych całego organizmu (JOST i współaut. 1973). Jednak w świetlne nowszych badań model ten wydaje się zbyt ogólny. Ostatnie badania sugerują, że płciowe różnicowanie osobnika jest zależne bezpośrednio od obecności chromosomów płci w osobnych komórkach jego organizmu, które maja swoja wewnętrzna płciowa tożsamość (HIRST i współaut. 2018). Dowodem na działanie chromosomów płci bezpośrednio na fizjologię komórek sa opisane trzy przypadki gynandromorficznych kur (organizm majacy jednocześnie męskie i żeńskie cechy płciowe, często wykazujący dwustronna asymetrię, gdy jedna połowa wykazuje cechy męskie, a druga żeńskie), będących płciowymi chimerami, u których jedna połowa ciała miała cechy samca, druga zaś samicy (ZHAO i współaut. 2010). Okazało się, że po stronie osobnika o budowie męskiej większość komórek miała genotyp ZZ, a po stronie żeńskiej ZW (Ryc. 2). Jądra rozwijały się, gdy większość komórek miała chromosomy ZZ, a jajniki, gdy ilościowo dominowały komórki ZW. Taka budowa ciała chimery nie może wynikać więc $z$ działania hormonów płciowych, gdyż rozprowadzane sa one $\mathrm{w}$ całym orga-

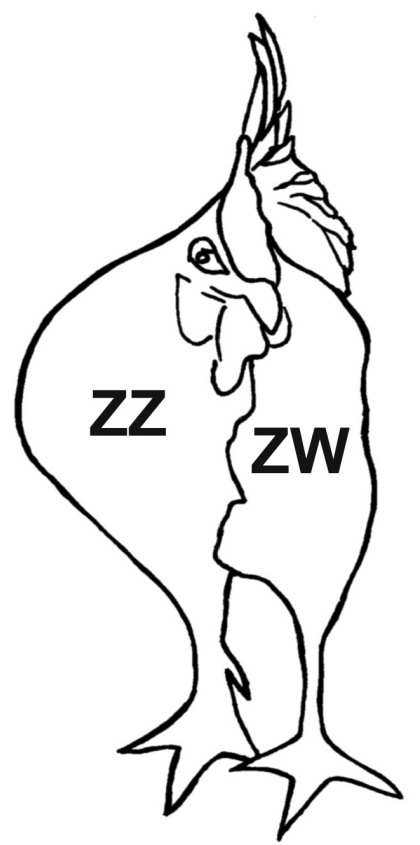

Ryc. 2. Gynandromorfia u kury domowej.

Prawa strona osobnika, posiadajaca chromosomy płci ZZ, ma cechy koguta - obecna ostroga na skoku. Lewa strona osobnika posiadajaca chromosomy płci $\mathrm{ZW}$, ma cechy kury. 
nizmie wraz $z$ krwia i doprowadziłyby do jednolitego płciowego różnicowania się całego organizmu.

Mimo takich wyjatków, fizjologiczna rola hormonów płciowych w płciowym rozwoju ptaków jest znacząca. Estradiol jest hormonem kluczowym dla rozwoju jajników. Zablokowanie jego syntezy doprowadza do maskulinizacji (pojawienie się męskich cech u osobnika płci żeńskiej) osobników ZW (genetyczne samice). Natomiast podanie estradiolu lub zwiększenie ekspresji genu aromatazy CYP19A1, odpowiedzialnego za syntezę estradiolu, doprowadza do przejściowej feminizacji osobników ZZ (genetyczne samce) (SCHEIB 1983, LAMBETH i współaut. 2013, VAILlANT i współaut. 2001). Natomiast gonadektomia wywołuje przejawy odwrócenia płci oraz zmiany zachowania osobników i ich upierzenia (OWENS i SHORT 1995, LAMBETH i SMITH 2012). Powyższe obserwacje wskazuja, że zarówno działanie genomu w komórkach różnych narządów, jak i hormonów płciowy$\mathrm{ch} \mathrm{w}$ organizmie pełni istotne funkcje w wykształcaniu u kur cech charakterystycznych dla danej płci.

\section{CHROMOSOMY PŁCI U KURY DOMOWEJ}

Kurzy męski chromosom $Z$ jest wielkości $82,3 \mathrm{Mb}$ (mega par zasad), zawiera ponad 1000 genów, $z$ czego większość to geny metabolizmu podstawowego, czyli ulegające ciagłej ekspresji (HANDLEY i współaut. 2004) (Ryc. 3). W trakcie ewolucji na chromosomie $\mathrm{Z}$ zgromadziło się wiele genów ulegających

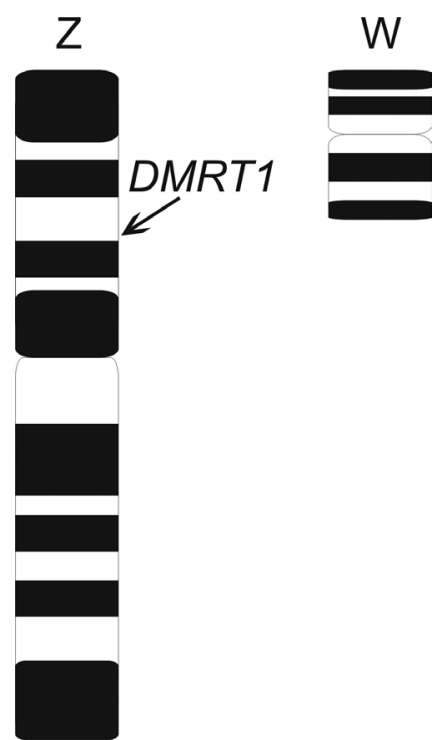

Ryc. 3. Chromosomy płci kury domowej.

Chromosom $Z$ jest znacznie większy od chromosomu W. Oznaczono położenie genu DMRT1 w chromosomie $Z$. ekspresji wyłącznie u samców i genów związanych $z$ płcią i rozmnażaniem. Między innymi znajdują się w nim geny DMRT1 (ang. doublesex and mab-3 related transcription factor 1) i HEMGN (hemogen), które ulegaja ekspresji w trakcie rozwoju jąder, co sugerowało, że chromosom $Z$, odpowiada za determinację płci (HIRST i współaut. 2018). $\mathrm{W}$ przeciwieństwie do chromosomu $\mathrm{Z}$, w żeńskim chromosomie $\mathrm{W}$ nie odnaleziono jak dotą żadnego genu determinującego płeć. Chromosom W jest mała, zdegradowana forma chromosomu $Z$ (Ryc. 3). Zawiera on 7 $\mathrm{Mb}$ DNA, co stanowi jedynie 6\% wielkości chromosomu Z. Większa część jego DNA jest silnie skondensowana i nieaktywna (heterochromatyna); reszta chromosomu W zawiera jedynie 28 genów kodujacych białka (HIRST i współaut. 2018). Geny chromosomu W maja swoje odpowiedniki na chromosomie $Z$ i ulegaja ekspresji na podobnym poziomie. $Z$ tych powodów nie moga być one genami determinujacymi płeć. Tak więc genów determinacji płci u kury domowej należałoby raczej szukać na chromosomie $Z$. Innymi słowy, u kury domowej płeć męska jest aktywnie determinowana przez obecność chromosomu $Z$, a płeć żeńska wydaje się być determinowana par défaut, czyli przy braku ekspresji genów zgromadzonych w chromosomie $\mathrm{Z}$.

\section{ROZWÓJ GONAD KURY DOMOWEJ}

Zawiazki gonad, zwane grzebieniami płciowymi, powstaja w zarodkach kury domowej jako zgrubienia nabłonka celomatycznego na brzusznej powierzchni płodowych nerek (śródnercze; gr. mesonephros) w 3. dniu inkubacji naturalnej i sztucznej (PIPREK i współaut. 2016). Również w 3. dniu inkubacji komórki prapłciowe, najwcześniejsze $z$ linii komórek płciowych, migruja naczyniami krwionośnymi $z$ półksiężyca płciowego położonego pozazarodkowo do rozwijającego się ciała osobnika (GINSBURG i EYAL-GILADI 1987). Niezróżnicowane płciowo gonady składaja się ze zgrubionego nabłonka celomatycznego (kora gonady) oraz $z$ centralnie położonego rdzenia gonady (Ryc. 4). Komórki linii płciowej znajduja się w korze gonady. Płciowe różnicowanie się gonad, a więc wykształcenie cech charakterystycznych dla jąder lub jajników, następuje u kury tuż po rozpoczęciu 6. dnia inkubacji. U samców (ZZ) kora staje się cieńsza, pozbawiona komórek linii płciowej, natomiast rozwija się rdzeń gonady, w którym wyodrębniają się sznury jądrowe zawierajace komórki linii płciowej i będące zawiązkami kanalików plemnikotwórczych (Ryc. 4). Komórki linii płciowej w sznurach jądrowych otoczone sa 

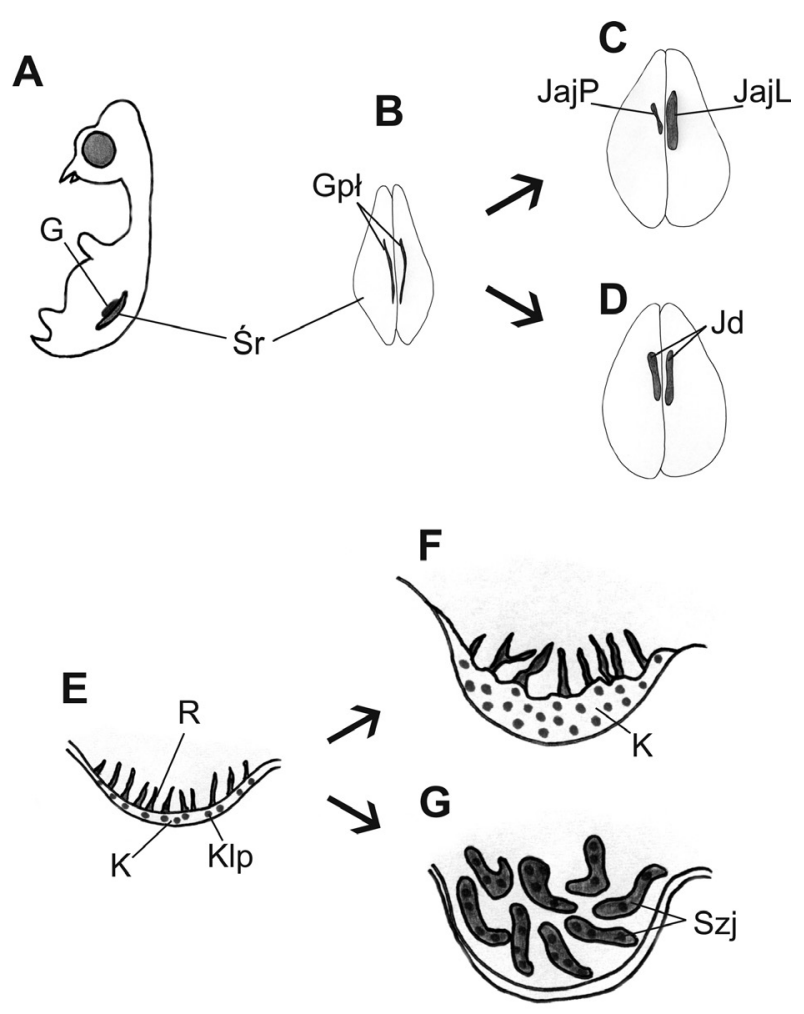

Ryc. 4. Rozwój gonad u kury domowej.

A. Gonady (G) w płodach ptaków rozwijają się po brzusznej stronie śródnerczy (Śr). B. Grzebienie płciowe (Gpł) powstaja około 4 dnia inkubacji. C. Asymetria w rozwoju jajników - lewy jajnik (JajL) dobrze rozwinięty, prawy (JajP) ulega redukcji. D. Rozwijające się jądra (Jd). E. Schemat przekroju poprzecznego przez gonadę niezróżnicowaną; widoczny podział na peryferycznie położoną korę gonady $(\mathrm{K}) \mathrm{z}$ komórkami linii płciowej (Klp), oraz na rdzeń gonady (R) ze sznurami płciowymi. F. Przekrój przez rozwijający się lewy jajnik; silny rozwój kory zawierającej komórki linii płciowej; zanikające sznury w obrębie rdzenia. G. Przekrój przez rozwijające się jądro; gonada męska pokryta ścieniała kora pozbawiona komórek linii płciowej; w centrum gonady obecne sznury jądrowe (Szj) powstałe $\mathrm{z}$ rdzenia gonady i zawierające komórki linii płciowej.

przez różnicujace się komórki Sertoliego, które wydzielaja białko zwane hormonem anty-müllerowskim (AMH) prowadzace do zaniku zawiązków jajowodów u płci męskiej. Pomiędzy sznurami jądrowymi rozwija się tkanka interstycjalna, zawierajaca płodowe komórki Leydiga, które produkuja hormony płci męskiej (androgeny), kierujące kształtowaniem się męskich cech płciowych.

W gonadach samic (ZW) zachodza zmiany przeciwne: kora zawierająca komórki linii płciowej rozwija się intensywnie, a rdzeń się zmniejsza (CARLON i STAHL 1985) (Ryc. 4). Komórki linii płciowej w korze gonady rozpoczynaja mejoze i tworza się pecherzyki jajnikowe zawierajace oocyty diplotenowe. W rozwoju gonad żeńskich u ptaków występuje daleko idąca asymetria. Kora lewej gonady zaczyna proliferować i rosnąć, podczas gdy prawa gonada cofa się w rozwoju i zmniejsza. W lewym różnicujacym się jajniku dochodzi do ekspresji czynnika transkrypcyjnego PITX2 (ang. paired like homeodomain 2), który wzmaga ekspresję receptora estrogenowego a, odpowiadajacego za zwiększenie proliferacji kory lewej gonady i jej różnicowanie się (GUIOLI i LOVELL-BADGE 2007, ISHIMARU i współaut. 2008, RORIGUEZ-LEON i współaut. 2008). Natomiast komórki linii płciowej w rdzeniu jajników i w całym prawym jajniku zostaja zatrzymane $\mathrm{w}$ mejozie i ulegaja programowanej śmierci komórkowej (apoptozie) tuż po wykluciu (DE MElo Bernardo i współaut. 2015). Po usunięciu lewego jajnika lub po jego zniszczeniu przez proces chorobowy prawa gonada ZW rozwija się $\mathrm{w}$ jądro (GROENENDIJK-HUIJBERS 1965, 1967). Wskazuje to, że u samic lewa gonada, prawdopodobnie przez działanie estrogenów, doprowadza do zahamowania rozwoju prawej gonady.

\section{MOLEKULARNE MECHANIZMY KIERUJĄCE ROZWOJEM GONAD ŻENSKICH}

Wiele eksperymentów wskazuje, że w rozwoju jajników kury domowej kluczowa rolę odgrywaja żeńskie hormony płciowe czyli estrogeny (ELBRECHT i SMITH 1992, VAILlANT i współaut. 2001). Podanie estradiolu do jaj $z$ rozwijającymi się płodami męskimi (ZZ) przed płciowym różnicowaniem się gonad doprowadza do powstania przejściowej feminizacji lewej gonady, czyli do wykształcenia gonady o cechach jajnika, lub gonad obojnaczych. Natomiast podanie substancji hamujących syntezę estrogenów (takich jak fadrazol) osobnikom ZW zaburza rozwój jajników i doprowadza do ich maskulinizacji (SCHEIB 1983).

Produkcja hormonów płciowych w rozwijajacych się gonadach zależy od ekspresji enzymów syntezy męskich hormonów, androgenów, które sa następnie konwertowane do estrogenów, gdy ekspresji ulega enzym aromataza (CYP19A1). Ekspresja tych enzymów jest płciowo specyficzna w trakcie rozwoju gonad ptaków (BRUGGEMAN i współaut. 2002). Enzymy syntezy androgenów ulegaja ekspresji w rdzeniu gonad $u$ obu płci, natomiast enzymy konwertujace androgeny do estrogenów (17ß-HSD i CYP19A1 - aromataza) ulegaja ekspresji w rdzeniu jedynie gonad ZW (samice) (SMITH i współaut. 1997, 2005). Tym samym estrogeny sa efektywnie produkowane tylko w rozwijających się jajnikach, a nie $\mathrm{w}$ jądrach, i 
odpowiadaja za rozwój jajników i żeńskich cech pozostałych narząów różnicujących się płciowo, jak na przykład mózgu.

Poza funcjami zależnymi od hormonów płciowych, zaangażowane są również geny bezpośrednio regulujące rozwój gonad. Pośród nich wyróżnia się gen FOXL2 (ang. forkhead box L2), który koduje bardzo istotny czynnik transkrypcyjny. Wiele badań pokazało, że gen ten ulega ekspresji w różnicujacych się jajnikach kręgowców począwszy od ryb, przez płazy, gady, ptaki po ssaki (LOFFLER i współaut. 2003, WANG i współaut. 2004, PISARSKA i współaut. 2011). U kur ekspresja FOXL2 rozpoczyna się w gonadach ZW tuż przed rozpoczęciem płciowego różnicowania się jajników i jeszcze przed ekspresja aromatazy. Nastepnie FOXL2 i gen kodujacy aromatazę ulegaja ekspresji w tych samych komórkach w rdzeniu gonad (Govoroun i współaut. 2004).

U myszy i ludzi wykazano, że WNT4 (ang. wingless-type MMTV integration site family, member 4) jest bardzo istotnym genem zaangażowanym w rozwój jajników (VAINIO i współaut. 1999, BIASON-LAUBER i współaut. 2007). Utrata tego czynnika doprowadza do odwrócenia płci męskiej w żeńską. U kury WNT4 ulega ekspresji w niezróżnicowanych gonadach $\mathrm{ZZ}$ i $\mathrm{ZW}$, a następnie zanika w różnicujących się jądrach i zostaje ograniczona do lewego jajnika (SMITH i współaut. 2008).

Kolejnym genem zaangażowanym w determinację płci żeńskiej jest RSPO1 (R-spondyna 1). Jej brak doprowadza do całkowitego odwrócenia płci żeńskiej w męska u ludzi (PARMA i współaut. 2006). W gonadach kury domowej gen RSPO1 ulega specyficznej p1ciowo ekspresji już w drugiej połowie czwartego dnia inkubacji, a więc przed rozpoczęciem płciowego różnicowania się gonad (SMith i współaut. 2008). Gen ten ulega silniejszej ekspresji w gonadach $Z \mathrm{~W}$, a mniejszej w ZZ, po czym jego ekspresja zostaje ograniczona do kory lewego jajnika w 12. dniu inkubacji. Produkty białkowe WNT4 i RSPO1, jako czynniki sygnalizacyjne, wspólnie przeciwdziałaja rozkładowi kolejnego białka, kateniny $\beta$, która jest czynnikiem transkrypcyjnym, a więc wpływa na ekspresję genów (CHASSOT i współaut. 2008; PIPREK 2009b). Białko FOXL2 wiąze się $z$ promotorem aromatazy prawdopodobnie regulujacc jej ekspresję i odwrotnie, zablokowanie aktywności aromatazy, a więc brak estrogenów, doprowadza do spadku ekspresji FOXL2 (FLEMING i współaut. 2010, HUDSON i współaut. 2005). Estrogeny sa konieczne dla ekspresji RSPO1 w korze jajnika. Ponadto, WNT4 i RSPO1 ulegają ekspresji w korze jajnika (SMITH i współaut. 2008), natomiast aromataza i FOXL2 w rdzeniu (GOVOROUN i współaut. 2004). Wskazuje to, że ekspresje tych genów (aromatazy, FOXL2, WNT4 i RSPO1) sa od siebie zależne i wchodzą w sieć interakcji.

Pomimo wielu badań, łacznie $Z$ wykorzystaniem globalnej analizy ekspresji genów w rozwoju gonad kury domowej (AYERs i współaut. 2015), nadrzędny gen determinujący płeć żeńska pozostaje nieznany. Zależności między genami zaangażowanymi w rozwój jajników wymagają więc dalszych badań.

\section{MOLEKULARNE MECHANIZMY KIERUJACE ROZWOJEM GONAD MESKICH}

Gen DMRT1 jest najbardziej prawdopodobnym kandydatem na gen determinujacy płeć u ptaków. Gen ten koduje czynnik transkrypcyjny i ulega ekspresji w rozwijajacych się gonadach męskich wszystkich kręgowców (SMith i współaut. 1999). U ptaków jest on zlokalizowany na chromosomie $Z$. Samce ZZ posiadaja dwie kopie tego genu, a samice ZW jedna. Gen ten ulega ekspresji w komórkach somatycznych i komórkach linii płciowej gonad obu płci, ale wyższy poziom jego ekspresji obserwuje się w gonadach męskich (ZZ) (OMOTEHARA i współaut. 2014). Po zablokowaniu syntezy estrogenów (np. przez chemiczna inhibicję aromatazy) dochodzi do wzrostu ekspresji DMRT1 w gonadach ZW (genetyczne samice), co następnie prowadzi do różnicowania się tych gonad w jądra, a więc do maskulinizacji gonad (SMITH i współaut. 2003). I przeciwnie, obniżenie ekspresji DMRT1 (wyciszenie za pomoca interferencji RNA) doprowadza do feminizacji gonad ZZ u genetycznych samców (SMITH i współaut. 2009). W sfeminizowanych gonadach wykształca się struktura typowa dla jajników, obniża się ekspresja genów charakterystycznych dla rozwoju jąder, jak SOX9 (SRY-box 9) i AMH oraz wyzwala się ekspresja genów charakterystycznych dla jajników (aromataza i FOXL2). Nadekspresja DMRT1 u samic kury (ZW) daje odwrotne efekty; powstaje tkanka o cechach jadra, wyciszeniu ulegaja geny jajnikowe $\mathrm{i}$ dochodzi do wyzwolenia ekspresji genów charakterystycznych dla jader: SOX9 i AMH (LAMBETH i współaut. 2014).

Dotychczasowe badania sugerowały, że DMRT1 jest nadrzędnym genem determinujacym płeć męską u ptaków i włącza kaskadę genów (szereg genów, w którym każdy gen wpływa na ekspresje kolejnego) odpowiedzialnych za różnicowanie się gonad męskich. Jednym $z$ głównych genów różnicowania się jąder u kręgowców jest gen SOX9. Suge- 
rowano, że u kury domowej białko HEMGN (homogen) jest elementem kaskady genów pomiędzy DMRT1 a SOX9 (NAKATA i współaut. 2013). HEMGN ulega ekspresji w gonadach $\mathrm{ZZ}$, a jego nadekspresja $\mathrm{u}$ osobników ZW doprowadza do maskulinizacji gonad (rozwój jąder i ekspresja SOX9). Nie wiadomo jednak jeszcze jak dokładnie wyglądaja zależności między tymi genami.

Kolejnym białkiem, potencjalnie zaangażowanym w determinację płci męskiej, jest FGF9 (czynnik wzrostu fibroblastów 9). Wiadomo, że kodujacy je gen ulega wysokiej ekspresji w mysich gonadach $\mathrm{XY}$, a jego zablokowanie doprowadza do feminizacji gonad (KIM i współaut. 2006, PIPREK 2009a). Nie odnaleziono jednak płciowo-specyficznych różnic w ekspresji FGF9 w płodowych gonadach kury (AYERS i wspólaut. 2015). Tym samym wydaje się, że prawdopodobnie gen ten nie jest zaangażowany $\mathrm{w}$ determinację płci ptaków. Zarówno enzym zwany syntaza prostaglandyny D2 (PGDS), jak i syntetyzowana dzięki jego działaniu prostaglandyna D2 sa zaangażowane $\mathrm{w}$ determinacje płci u myszy (WILHELM i współaut. 2007). Prostaglandyna ta podwyższa ekspresję genu SOX9, który jest kluczowy dla rozwoju jąder myszy (MONIOT i współaut. 2009). U kury, wykazano wyższa ekspresje genu PGDS w rozwoju gonad ZZ (MONIOT i współaut. 2008). Dodanie prostaglandyny D2 do pożywki $z$ hodowanymi w warunkach in vitro płodowymi gonadami $\mathrm{ZW}$ kury doprowadziło do wyzwolenia ekspresji genu SOX9, ale nie do maskulinizacji gonad (Moniot i współaut. 2008). Sugeruje to, że prostaglandyna D2 jest $\mathrm{w}$ pewien sposób zaangażowana $\mathrm{w}$ kontrolę ekspresji genów zaangażowanych w rozwój jąder nie tylko myszy, ale także kury. Trudno jednak dzisiaj okreslić specyfikę jej działania.

$\mathrm{AMH}$ (hormon anty-müllerowski) jest kluczowym białkiem sygnalizacyjnym w procesie różnicowania płciowego, gdyż jest wydzielany przez różnicujące się komórki Sertoliego w płodowych jadrach, skad dyfunduje do przewodów Müllera (zawiązki jajowodôw) i powoduje ich zanik u płci męskiej. Ten sposób regulacji morfogenezy ma znaczenie dla prawidłowego różnicowania się cech płciowych męskich, gdyż powoduje, że jajowody nie wykształcaja się u osobników płci męskiej. U myszy, gen $A M H$ ulega ekspresji pod kontrola nadrzędnego w stosunku do niego genu SOX9 (DE SANTA BARBARA i współaut. 1998). Natomiast inna sytuacja ma miejsce u kury domowej. Tutaj $A M H$ ulega ekspresji wczešniej, już w gonadach niezróżnicowanych, a więc jeszcze przed wyzwoleniem ekspresji SOX9. $Z$ tego wynika jasno, że $A M H$ nie jest regulowany przez SOX9. Ponadto, receptor tego hormonu (AMHR) ulega ekspresji nie tylko w przewodach Müllera, ale także w samych gonadach kury. Zapewne $\mathrm{z}$ tego powodu zablokowanie ekspresji genu $A M H$ u tego gatunku doprowadza do zmniejszenia rozmiarów gonad, w wyniku spowolnienia proliferacji ich komórek (LAMBETH i współaut. 2015). Wskazuje to, że zahamowanie rozwoju jajowodów u płci męskiej kur nie jest jedyna funkcja hormonu anty-müllerowskiego i hormon ten odgrywa także ważną rolę w rozwoju samych gonad. Ponadto, opisane wyżej badania dowodza, że geny biorace udział $\mathrm{w}$ rozwoju gonad kręgowców pełnia także inne funkcje, które moga być bardzo zróżnicowane w poszczególnych taksonach.

\section{ROZWÓJ DRUGORZEDOWYCH CECH PŁCIOWYCH U KUR}

Za rozwój cech płciowych u kur odpowiadaja zarówno hormony płciowe produkowane przez gonady, jak również wewnętrzna tożsamość płciowa komórek ciała. Geny ulegajace ekspresji w komórkach różnych narządów organizmu, prowadzą do rozwoju specyficznych cech obu płci, takich jak masa ciała i tempo wzrostu. Różnicowanie płciowe doprowadza do rozwoju ostróg na skoku samca, korali i grzebienia na jego głowie. Jest to efekt działania testosteronu (LAMBETH i współaut. 2016). Usunięcie jajników u pewnych odmian kur powoduje u nich wzrost ostróg do rozmiarów charakterystycznych dla samców, co sugeruje, że kontrola rozwoju tych tworów jest bardziej skomplikowana i prawdopodobnie estrogeny produkowane przez jajniki powoduja zahamowanie tworzenia się ostróg u samic (VALDEZ i współaut. 2010). Kolejne cechy płciowe dotycza upierzenia, które u samców jest bardziej barwne i szczególnie obfite na kuprze. U ptaków grzebiących (kury, indyki itd.) upierzenie samicy jest determinowane przez estrogeny, natomiast upierzenie samca rozwija się przy braku estrogenów (OwENs i SHORT 1995), a więc par défault. To oznacza, że rozwój upierzenia samca jest realizacja planu rozwojowego o charakterze podstawowym, w przeciwieństwie do planu rozwojowego upierzenia samicy, który wymaga impulsu w postaci wspomnianych hormonów. W przeciwieństwie do ptaków grzebiących, u ptaków wróblowych upierzenie samca rozwija się pod wplywem testosteronu (LiNDSAY i współaut. 2011), co wskazuje na zróżnicowany udział hormonów w wykształceniu dymorfizmu płciowego ptaków.

Różnicowanie płciowe dotyczy także mózgu ptaków. Odmiennie u obu płci rozwija się ośrodek odpowiedzialny za śpiew u 
ptaków śpiewajacych (Oscines). Ośrodek śpiewu nazywany jest HVC (łac. hyperstriatum ventrale, pars caudalis; ang. high vocal center) i znajduje się na terenie nidopallium, które jest częścią kory kresomózgowia ptaków. Rozwój tego ośrodka odbywa się niezależnie od hormonów płciowych i jest kontrolowany bezpośrednio przez ekspresję genów w komórkach mózgu, a więc zależy od wewnętrznej tożsamości płciowej komórek mózgu ZZ lub ZW (AGATE i współaut. 2003).

\section{ROLA HORMONÓW W ROZWOJU PECIOWYM}

Aromataza (CYP19A1) ulega ekspresji w gonadach $\mathrm{ZW}$ (u genetycznych samic) kury domowej od 6. dnia inkubacji jaj. W korze rozwijającego sie jajnika, a w mniejszym stopniu też $\mathrm{w}$ jego rdzeniu, ekspresji ulega receptor estrogenowy (ERa), przez co hormony płciowe żeńskie moga wpływać na rozwój jajnika (ANDREWS i współaut. 1997). Wstrzyknięcie do jaja fadrazolu, który blokuje enzym aromatazę, hamuje syntezę estrogenów. Taki zabieg doprowadza do maskulinizacji, czyli do rozwoju osobników ZW o cechach męskich. Osobniki te zazwyczaj rozwijaja się $\mathrm{w}$ fenotypowe samce, co nazywamy odwróceniem płci (ElBRECHT i SMITH 1992). U takich maskulinizowanych osbników niekiedy obserwowano gonady obojnacze (ovo-testis). Gonada obojnacza ptaków ma zgrubiała korę, jak jajnik, oraz kanaliki plemnikotwórcze w rdzeniu, jak jacdro. Prawa gonada ma silniejsze tendencje do rozwoju struktur charakterystycznych dla jądra. W jądrach takich osobników ZW powstaja kanaliki plemnikotwórcze, w których rozwijaja się plemniki mogace uczestniczyć w zapłodnieniu (ElBRECHT i SMITH 1992). Komórka linii płciowej, posiadając chromosom $Z$, rozwija się $\mathrm{w}$ plemnik, natomiast komórka linii płciowej $z$ chromosomem $\mathrm{W}$ nie ma zdolności do rozwinięcia się w plemnik, a do zapłodnienia za pomoca komórki $z$ chromosomem $\mathrm{W}$ może dojść jedynie na drodze metod wspomaganego rozrodu (TAKAGI i współaut. 2007).

$Z$ kolei wstrzyknięcie estrogenów do jaj $z$ rozwijajacymi się płodami $Z Z$, tuż przed ich płciowym różnicowaniem się, doprowadza do lekkiej feminizacji gonad (SCHEIB 1983). W gonadach takich osobników silniej grubieje kora gonad, a zmniejsza się ich rdzeń. Jednak efekt ten jest przejściowy i zanika po wylęgu. Tak więc obecność dwóch chromosomów $Z$ niweluje efekt działania egzogennych estrogenów.

Dobrze udokumentowana jest rola estrogenów w rozwoju jajników ptaków, natomiast rola testosteronu $\mathrm{w}$ rozwoju jąder została poznana dość słabo. Receptor androge- nowy (AR) ulega wyższej ekspresji w rozwijajacych się jajnikach niż w jądrach kury (KATOH i współaut. 2006), co wskazuje, że męskie hormony płciowe moga pełnić pewna rolę w rozwoju jajników. Jednak, poziom testosteronu $\mathrm{w}$ płodach kury obu płci podczas ich rozwoju jest wręcz niewykrywalny, co wskazuje, że udział androgenów w rozwoju płodowym kur może być znikomy.

Jedna $z$ metod badania udziału hormonów w rozwoju płciowym sa przeszczepy gonad. Przeszczepienie rozwijającego się jądra w okolice niezróżnicowanych jeszcze gonad zarodków ZW doprowadza do ich maskulinizacji w trakcie dalszego rozwoju (MARNAUD i współaut. 1990). Nie wiadomo w jaki sposób wszczepiona gonada męska indukuje rozwój gonad ZW w kierunku jąder. Wykazano, że w tym przypadku ani androgeny, ani czynnik AMH wydzielany przez gonade męska nie doprowadza do maskulinizacji gonad ZW.

\section{ZABURZENIA CHROMOSOMALNE A ODWRÓCENIE PECI U PTAKÓW}

Istotnych informacji na temat determinacji płci dostarczaja badania osobników aneuploidalnych o genotypie $Z 0$ i ZZW. Tego typu aneuploidie sa niezwykle rzadkie u ptaków i sa letalne w okresie płodowym (GRAVES 2003). Natomiast częstsze i bardziej żywotne sa triploidie kur (3A:ZZZ i 3A:ZZW), u których cały genom uległ zwielokrotnieniu (TIERSCH i współaut. 1991). Osobniki ZZZ rozwijaja się w prawidłowe samce, jednak ich spermatogeneza jest zaburzona (THORNE i SHELDON 1993), natomiast osobniki 3A:ZZW to bezpłodne obojnaki, posiadajace $\mathrm{w}$ momencie wyklucia obojnacza gonadę (ovo-testis) po lewej stronie ciała i jądro po prawej (TIERSch i współaut. 1991). Podczas dalszego wzrostu komponenta jajnikowa zanika, przez co obojnacza gonada przekształca się w jądro. Rozwój gonad osobników ZZW w ovo-testis wskazuje, że podwojony chromosom $Z$ powoduje rozwój rdzenia $\mathrm{w}$ kanaliki plemnikotwórcze, natomiast obecność chromosomu W wplywa na rozwój kory gonady w kierunku jajnika. Dalsze badania powinny wyjaśnić czy u ptaków, podobnie jak u muszki owocowej, kluczowy w determinacji płci jest stosunek liczby chromosomów płci do autosomów; w przypadku ptaków jest to stosunek liczby chromosomów $Z$ do liczby chromosomów autosomalnych.

\section{KOMPENSACJA DAWKI GENÓW CHROMOSOMÓW PECI}

Genomy samców i samic kury domowej różnia się znacznie liczbą genów. W komórkach samców ptaków obecne sa 
dwa chromosomy $Z$, które koduja setki istotnych genów, natomiast $\mathrm{u}$ samic obecny jest tylko jeden, ubogi $\mathrm{w}$ geny chromosom $Z$. Samce i samice potencjalnie powinny różnić się poziomem ekspresji niektórych genów. Samce ptaków (ZZ) maja podwójna liczbę kopii genów chromosomu $Z$. Aby wyrównać te różnice dochodzi do kompensacji liczby genów chromosomów płci, co jest zjawiskiem powszechnym wśród zwierząt posiadajacych takie chromosomy. U ptaków nie dochodzi do ogólnego wyciszenia chromosomu Z. Zachodzi natomiast częściowe wyciszenie ekspresji niektórych genów chromosomu $Z$, by wyrównać poziom ich ekspresji z samicami ZW (CocK 1964, MCQuEEN $\mathrm{i}$ CLINTON 2009). Wskazuje to na istnienie u ptaków wyjątkowego mechanizmu kompensacji liczby genów chromosomów płci, nieopisanego $\mathrm{u}$ innych grup zwierzat. Dlatego poznanie procesów płciowej detreminacji i różnicowania gonad jest szczególnie interesujące $z$ punktu widzenia biologii rozwoju i zrozumienia przebiegu ewolucji.

$$
\text { Streszczenie }
$$

Poznanie procesu determinacji płci i rozwoju płciowego ptaków zawdzięczamy głównie badaniom kury domowej. U gatunku tego, jak u reszty ptaków, płcia heterogametyczna jest płeć żeńska (ZW), a homogametyczna jest płeć męska (ZZ). Jak dotąd nieznany jest nadrzędny gen determinujący płeć ptaków. Za kluczowy gen uznaje się DMRT1, który znajduje się na chromosomie $\mathrm{Z}$ i ulega ekspresji $\mathrm{w}$ rozwijajacych się gonadach męskich. Natomiast w rozwoju gonad żeńskich kluczowa rolę odgrywa aromataza, enzym odpowiedzialny za syntezę estrogenów. Geny potencjalnie zaangażowane w determinacje płci ulegaja ekspresji w rozwijajacych się gonadach. U ptaków jajnik i jajowód rozwijaja się jedynie po stronie lewej, natomiast prawa gonada ulega znacznej redukcji. Okazuje się, że estrogeny odgrywaja istotna rolę w rozwoju płciowym ptaków. Modulujac aktywność aromatazy można uzyskiwać osobniki o odwróconej płci. Rola testosteronu w rozwoju gonad kur jest niejasna, natomiast opisano jego rolę $\mathrm{w}$ rozwoju drugorzędowych cech płciowych. Zestawienie dotychczasowych badań nad determinacja płci u ptaków wskazuje, że dalsze badania sa konieczne dla pełnego poznania tego procesu.

\section{LITERATURA}

Agate R. J., GRISHAM W., WADE J., MANN S., Wingfield J., Schanen C., Palotie A., ARNOLD A. P., 2003. Neural, not gonadal, origin of brain sex differences in a gynandromorphic finch. Proc. Natl. Acad. Sci. USA 100, 48734878.

ANDRews J. E., SMith C. A., Sinclair A. H., 1997. Sites of estrogen receptor and aromatase ex pression in the chicken embryo. Gen. Comp. Endocrinol. 108, 182-190.

AyerS K. L., Lambeth L. S., Davidson N. M., SinCLAIR A. H., OSHLACK A., SMITH C. A., 2015. Identification of candidate gonadal sex differentiation genes in the chicken embryo using RNA-seq. BMC Genomics 16, 704
Biason-Lauber A., DE FILIPPO G., KONRAD D., SCARANO G., NAZZARO A., SCHOENLE E. J., 2007. WNT4 deficiency-a clinical phenotype distinct from the classic Mayer-Rokitansky-Kuster-Hauser syndrome: a case report. Hum. Reprod. 22, 224-229.

BRUgGeman V., VAN As P., DECUYPERE E., 2002. Developmental endocrinology of the reproductive axis in the chicken embryo. Comp. Biochem. Physiol. A Mol. Integr. Physiol. 131, 839-846.

CARLON N., STAHL A., 1985. Origin of the somatic components in chick embryonic gonads. Arch. Anat. Microsc. Morphol. Exp. 74, 52-59.

CHASSOT A. A., RANC F., GREgOIRE E. P., Roepers-Gajadien H. L., TAKeto M. M., CAmeRINO G., DE RoOIJ D. G., Schedl A., CHABOISSIER M. C., 2008. Activation of beta-catenin signaling by Rspo1 controls differentiation of the mammalian ovary. Hum. Mol. Genet. 17, 1264-1277.

Cock A. G., 1964. Dosage compensation and sex chromatin in non-mammals. Genet. Res. 5, 354-365.

de Melo Bernardo A., HeEren A. M., VAN IpeREN L., FERnANDES M. G., HE N., ANJIE S., Noce T., Ramos E. S., DE Sousa Lopes S. M., 2015. Meiotic wave adds extra asymmetry to the development of female chicken gonads. Mol. Reprod. Dev. 82, 774-786.

DE SANTA Barbara P., Bonneaud N., Boizet B., DesclozeauX M., MONIOT B., SUDBECK P., Scherer G., POUlat F., BerTA P., 1998. Direct interaction of SRY-related protein SOX9 and steroidogenic factor 1 regulates transcription of the human anti-Mullerian hormone gene. Mol. Cell Biol. 18, 6653-6665.

ElbRECHT A., SMith R. G., 1992. Aromatase enzyme activity and sex determination in chickens. Science 255, 467-470.

Fleming N. I., KNOWER K. C., LAZARUS K. A., Fuller P. J., Simpson E. R., Clyne C. D., 2010. Aromatase is a direct target of FOXL2: C134W in granulosa cell tumors via a single highly conserved binding site in the ovarian specific promoter. PloS One 5, e14389.

GinsBURG M., EYAL-GILADI H., 1987. Primordial germ cells of the young chick blastoderm originate from the central zone of the area pellucida irrespective of the embryo-forming process. Development 101, 209-219.

Govoroun M. S., PANNETIER M., PAILHOux E., COCQUeT J., BRILlaRD J. P., COUTY I., BATElliER F., COTINOT C., 2004. Isolation of chicken homolog of the FOXL2 gene and comparison of its expression patterns with those of aromatase during ovarian development. Dev. Dyn. 231, 859-870.

GRAVES J. A., 2003 Sex and death in birds: a model of dosage compensation that predicts lethality of sex chromosome aneuploids. Cytogenet. Genome Res. 101, 278-282.

GRAVES J. A., 2016. Evolution of vertebrate sex chromosomes and dosage compensation. Nat. Rev. Genet. 17, 33-46.

GROENENDIJK-HUIJBERS M. M., 1965. The right ovary of the chick embryo after early sinistral castration. Anat. Rec. 153, 93-99.

GROENENDIJK-HUIJBERS M. M., 1967. Experimental studies concerning the compensatory growth of the rudimentary right ovary of sinistrally castrated chick embryos. Verh. Anat. Ges. 62, 321-325.

GuIOLI S., LOVELL-BADGE R., 2007. PITX2 controls asymmetric gonadal development in both sexes of the chick and can rescue the degener- 
ation of the right ovary. Development 134, 4199-4208.

Handley L. J., Ceplitis H., Ellegren H., 2004. Evolutionary strata on the chicken $Z$ chromosome: implications for sex chromosome evolution. Genetics 167, 367-376.

Hirst C. E., Major A. T., Smith C. A., 2018. Sex determination and gonadal sex differentiation in the chicken model. Int. J. Dev. Biol. 62, 153-166.

Hudson Q. J., Smith C. A., Sinclair A. H., 2005. Aromatase inhibition reduces expression of FOXL2 in the embryonic chicken ovary. Dev. Dyn. 233, 1052-1055.

ISHIMARU Y., KOMATSU T., KASAHARA M., KATOH-FuKUi Y., OGAWA H., TOYAMA Y., MAEKAWA M., TOSHIMORI K., CHANDRARATNA R. A., MOROHASHI K., YOSHIOKA H., 2008. Mechanism of asymmetric ovarian development in chick embryos. Development 135, 677-685.

Jost A., Vigier B., PrePin J., PERChellet J. P., 1973. Studies on sex differentiation in mammals. Recent Prog. Horm. Res. 29, 1-41.

Katoh H., OGINO Y., YAMADA G., 2006. Cloning and expression analysis of androgen receptor gene in chicken embryogenesis. FEBS Lett. 580, 1607-1615.

Kim Y., Kobayashi A., SEKIDO R., DiNAPOLI L., Brennan J., Chaboissier M. C., POUlat F., BeHRinger R. R., LOVEll-BadGe R., CAPEl B., 2006. Fgf9 and Wnt4 act as antagonistic signals to regulate mammalian sex determination. PLoS Biol 4, e187.

KRAUTWALD-JUnghanNS M. E., CRAMER K., FisCHER B., Förster A., Galli R., Kremer F., Mapesa E. U., MEISSNER S., PREISINGER R., PREUSse G., Schnabel C., Steiner G., Bartels T., 2018. Current approaches to avoid the culling of day-old male chicks in the layer industry, with special reference to spectroscopic methods. Poult Sci. 97, 749-757.

LAmBeth L. S., Smith C. A., 2012. Disorders of sexual development in poultry. Sex. Dev. 6, 96-103.

Lambeth L. S., Cummins D. M., DoRan T. J., SinCLAIR A. H., SMITH C. A., 2013. Overexpression of aromatase alone is sufficient for ovarian development in genetically male chicken embryos. PloS One 8, e68362.

LAMBeTH L. S., RAYMOND C. S., Roeszler K. N., KuROIWA A., NAKATA T., ZARKOWER D., SMITH C.A., 2014. Over-expression of DMRT1 induces the male pathway in embryonic chicken gonads. Dev. Biol. 389, 160-172.

LAMBETH L. S., AYERS K., CUTTING A. D., DORAN T. J., Sinclair A. H., SMITH C. A., 2015. Anti-Mullerian hormone is required for chicken embryonic urogenital system growth but not sexual differentiation. Biol. Reprod. 93, 138.

LAMBeth L. S., MORRIS K., Ayers K. L., WiSE T. G., O’Neil T., Wilson S., CaO Y., Sinclair A. H., CutTing A. D., Doran T. J., SMith C. A., 2016. Overexpression of Anti-Mullerian Hormone Disrupts Gonadal Sex Differentiation, Blocks Sex Hormone Synthesis, and Supports Cell Autonomous Sex Development in the Chicken. Endocrinology 157, 1258-1275.

LiNDSAY W. R., WeBsteR M. S., SCHWABL H., 2011. Sexually selected male plumage color is testosterone dependent in a tropical passerine bird, the red-backed fairy-wren (Malurus melanocephalus). PLoS One 6, e26067.

LOFFLER K.A., ZARKOWER D., KOOPMAN P., 2003. Etiology of ovarian failure in blepharophimosis ptosis epicanthus inversus syndrome: FOXL2 is a conserved, early-acting gene in vertebrate ovarian development. Endocrinology 144, 3237-3243.

MARAUD R., VERgnaUd O., RASHEDI M., 1990. New insights on the mechanism of testis differentiation from the morphogenesis of experimentally induced testes in genetically female chick embryos. Am. J. Anat. 188, 429-437.

McQueEn H. A., Clinton M., 2009. Avian sex chromosomes: dosage compensation matters. Chromosome Res. 17, 687-697.

MONIOT B., BOIZETI-BONHOURE B., POUlat F., 2008. Male specific expression of lipocalin-type prostaglandin $D$ synthase (cPTGDS) during chicken gonadal differentiation: relationship with cSOX9. Sex. Dev. 2, 96-103.

Moniot B., DEClOSMENIL F., BARRIONUEVO F., SCHERER G., ARITAKE K., MALKI S., MARZI L., COHEN-Solal A., GeORG I., KlatTig J., ENGLERT C., Kim Y., CAPEL B., EGUCHI N., URADE Y., BOIZET-BONHOURE B., POULAT F., 2009. The PGD2 pathway, independently of FGF9, amplifies SOX9 activity in Sertoli cells during male sexual differentiation. Development 136, 1813-1821.

NAKATA T., Ishiguro M., Aduma N., IZUmi H., KuROIWA A., 2013. Chicken hemogen homolog is involved in the chicken-specific sex-determining mechanism. Proc. Natl. Acad. Sci. USA 110, 3417-3422.

OMOTEHARA T., SMith C. A., MANTANi Y., KoBAYASHI Y., TATSUMI A., NAGAHARA D., HASHIMOTO R., HIRANO T., UMEMURA Y., YOKOYAMA T., KITAGAWA H., HOSHI N., 2014. Spatiotemporal expression patterns of doublesex and mab-3 related transcription factor 1 in the chicken developing gonads and Mullerian ducts. Poult. Sci. 93, 953-958.

OWENS I. P., SHORT R. V., 1995. Hormonal basis of sexual dimorphism in birds: implications for new theories of sexual selection. Trends Ecol. Evol. 10, 44-47.

PARMA P., RADI O., VIDAL V., ChABOISSIER M. C., Dellambra E., Valentini S., Guerra L., Schedl A., CAMERINo G., 2006. R-spondin 1 is essential in sex determination, skin differentiation and malignancy. Nat. Genet. 38, 13041309.

PIPREK R. P., 2009a. Genetic mechanisms underlying male sex determination in mammals. J. Appl. Genet. 50, 347-360.

PIPREK R. P., 2009b. Molecular mechanisms underlying female sex determination - antagonism between female and male pathway. Folia Biol. 57, 105-113.

PiPREK R. P., KlOC M., KuBIAK J. Z., 2016. Early development of the gonads: origin and differentiation of the somatic cells of the genital ridges. [W:] Molecular mechanisms of cell differentiation in gonad development. PIPREK R. P. (red.). Springer International Publishing, Cham, 1-22.

PisARskA M. D., BARLOW G., KUO F. T., 2011. Minireview: roles of the forkhead transcription factor FOXL2 in granulosa cell biology and pathology. Endocrinology 152, 1199-1208.

PREISINGER R., 2003. Sex determination in poultry - A primary breeder's view. Worlds Poult. Sci. J. 59, 54-58.

Rodriguez-LEON J., Rodriguez Esteban C., MARTI M., SANTIAGO-Josefat B., DUBOVA I., RUBIRalta X., IzPisua Belmonte, J. C., 2008. Pitx2 regulates gonad morphogenesis. Proc. Natl. Acad. Sci. USA 105, 11242-11247.

SCHEIB D., 1983. Effects and role of estrogens in avian gonadal differentiation. Differentiation 23, S87-S92. 
Smith C. A., ANDREws J. E., Sinclair A. H., 1997. Gonadal sex differentiation in chicken embryos: expression of estrogen receptor and aromatase genes. J. Steroid. Biochem. Mol. Biol. 60, 295-302.

SMith C. A., MCClive P. J., Western P. S., ReEd K. J., Sinclair A. H., 1999. Conservation of a sex-determining gene. Nature 402, 601-602.

SMITH C. A., KATZ M., SinClaIR A. H., 2003. $D M R T 1$ is upregulated in the gonads during female-to-male sex reversal in $Z W$ chicken embryos. Biol. Reprod. 68, 560-570.

Smith C. A., McClive P. J., Hudson Q., Sinclair A. H., 2005. Male-specific cell migration into the developing gonad is a conserved process involving PDGF signalling. Dev. Biol. 284 , 337-350.

Smith C. A., Shoemaker C. M., Roeszler K. N. QUeEN J., CREWS D., SinClaIR A. H., 2008. Cloning and expression of $R$-Spondin 1 in different vertebrates suggests a conserved role in ovarian development. BMC Dev. Biol. 8, 72.

Smith C. A., Roeszler K. N., OHNesorg T., CUMMins D. M., FARlie P. G., DORAN T. J., SinCLAIR A. H., 2009. The avian Z-linked gene DMRT1 is required for male sex determination in the chicken. Nature 461, 267-271.

TAKAGI S, ONO T, TSUKADA A, ATSUMI Y, MizUSHIMA S, SaITo N, ShIMAdA K., 2007. Fertilization and blastoderm development of quail oocytes after intracytoplasmic injection of chicken sperm bearing the $W$ chromosome. Poult Sci 86, 937-943.

THORNE M. H., SHELdON B. L., 1993. Triploid intersex and chimeric chickens: useful models for studies of avian sex determination. [W:] Sex Chromosomes and Sex-determining Genes. REED K., GRAVES J. A. M. (red.). Harwood Academic Publishers, Australia, 199-205.
TIERSCH T. R., BECK M. L., Douglass M., 1991. ZZW autotriploidy in a Blue-and-Yellow $\mathrm{Ma}$ caw. Genetica 84, 209-212.

VAILlant S., DORIzZI M., PIEAU C., Richard-MERCIER N., 2001. Sex reversal and aromatase in chicken. J. Exp. Zool. 290, 727-740.

VAinio S., HeikKILÄ M., KisPert A., ChIN N., MCMAHON A. P., 1999. Female development in mammals is regulated by Wnt-4 signalling. Nature 397, 405-409.

VAlDEZ M. B. JR., MizuTani M., Kinoshita K., FUJIWARA A., YAZAWA H. i współaut., 2010. Differential development of sex-related characters of chickens from the GSP and PNP/DO inbred lines after left ovariectomy. J. Reprod. Dev. $56,154-161$.

WANG D., KOBAYAShI T., ZHOU L., NAGAHAMA Y., 2004. Molecular cloning and gene expression of Foxl2 in the Nile tilapia, Oreochromis niloticus. Biochem. Biophys. Res. Commun. 320, 83-89.

WeST B., ZHOU B. X., 1988. Did chickens go north? New evidence for domestication.

J. Archaeol. Sci. 15, 515-533.

Wilhelm D., HiRAMATSU R., MiZusaki H., WidJAJA L., Combes A. N., KanaI Y., KOOPMAN P., 2007. SOX9 regulates prostaglandin $D$ synthase gene transcription in vivo to ensure testis development. J. Biol. Chem. 282, 1055310560.

Xu L., Sin S., Grayson P., Janes D. E., Edwards S. V., SACKTON T. B., 2018. Evolutionary dynamics of sex chromosomes of palaeognathous birds. bioRxiv, Cold Spring Harbor, doi: https://doi.org/10.1101/295089.

ZhaO D., MCBRIDE D., NANDI S., MCQueEN H. A., McGrew M. J., Hocking P. M., Lewis P. D. SANG H. M., Clinton M., 2010. Somatic sex identity is cell autonomous in the chicken. Nature 464, 237-242.

KOSMOS Vol. 68, 3, 389-398, 2019

RAFAE P. PiPREK ${ }^{1}$, JACEK Z. KUBiaK ${ }^{2,3}$

${ }^{1}$ Department of Comparative Anatomy, Institute of Zoology and Biomedical Research, Jagiellonian University, 9 Gronostajowa Str., 30-387 Kraków, '2UnivRennes, CNRS, UMR 6290, Institute of Genetics and Development of Rennes, Cell Cycle Group, Faculty of Medicine, F-35000 Rennes, France, ${ }^{3}$ Laboratory of Regenerative Medicine and Cell Biology, Military Institute of Hygiene and Epidemiology (WIHE), 4 Kozielska Str., 01-163 Warszawa, E-mail: rafal.piprek@uj.edu.pl

\section{SEX DETERMINATION AND GONAD DEVELOPMENT IN CHICKEN}

\section{Summary}

Our understanding of sex determination and sexual development in birds is based mainly on findings from chicken. In this species, as in other birds, female sex is heterogametic (ZW), and the male sex is homogametic (ZZ). So far, a master sex-determining gene is unknown. DMRT1 is considered as a crucial gene for the male sex determination. This gene is located in the $Z$ chromosome and is expressed in the developing male gonads. However, in ovarian development, aromatase, an enzyme synthesizing estrogens, appears critical. Interestingly, in birds, the ovary and oviduct develop only at the left side, while the right gonad becomes reduced. Estrogens have an important role in the sexual development in birds. Accordingly, a modulation of aromatase activity can be used to obtain birds with sex reversal. The exact role of testosterone in testis development remains unclear. However it was shown that this hormone plays an important role in the secondary sex features development. The compilation of previous findings reveals that further studies on sex determination in birds are required to fully describe this phenomenon.

Key words: aromatase, chicken, estrogenes, gonads, sex chromosomes, sex determination, sex hormones, sexual development, testosteron 